\title{
PERCEPTION AND OBSTACLES OF COLLEGE STUDENTS IN WRITING
}

\author{
Pande Agus Adiwijaya ${ }^{1}$, Ni Made Ayu Purnami², I Wayan S Arsana ${ }^{3}$, \\ ${ }^{1}$ English Education Department, STKIP Suar Bangli \\ ${ }^{2}$ English Education Department, STKIP Suar Bangli \\ ${ }^{2}$ Indonesian Language and Letters Education, STKIP Suar Bangli \\ 1adiwijayapande@gmail.com, ㄹmadeayupurnami21121991@yahoo.com, \\ 3iwayansoklatarsana@gmail.com
}

\begin{abstract}
This is a descriptive qualitative research which aimed at finding the perception and obstacles of college students in writing. The subject of this research was all of students in English Education Department of STKIP Suar Bangli in academic year 2018/2019. There were three instruments used in this research, namely questionnaire, interview and documentation. From the data analysis it was found that students of English Education Department considered writing was important for them and considered as the second most important skill after speaking. Teaching writing skill should be taught through the process of writing (drafting, writing and revising) in relax and fun situation with many practices. The evaluation of writing should also provide feedbacks for their writing improvement. The most challenging obstacle that should be solved by the students was finding ideas. The students also proposed some reasons that may trigger them to write such as having idea/inspiration, having assignment, being in a good mood, there is time allocation for writing, having motivation, and being in supportive situation and condition. It is also suggested to teach writing skill by using project-based learning through proper process of writing starting from pre-writing, drafting, writing, revision and editing. The evaluation was also in form of portfolio assessment.
\end{abstract}

Keywords : perception, obstacles, writing, college students

\section{INTRODUCTION}

Writing is one of complimentary subjects in English Education Department. Some writing activities including writing paper, thesis, report, proposal, articles and so on. However, some students still have problems in writing. They assume that writing is difficult, boring, notflexible, even some said it is not important. Whereas writing is one of effective ways to develop critical thinking, expressing ideas systematically, adding insight, and so on. According to Komaidi (2008), there are six benefits of writing which can be gained by the writer. First, writing could trigger curiosity and train sensitivity to see the surrounding. Second, through writing, the writer is forced to find references such as book, journal, magazine, newspaper, and others. By finding references, the writer could add his insights. Third, through writing, the writer is trained to organize the thought and argument orderly, systematically, and logically. 
Fourth, psychologically writing could decrease level of stress and tension. Fifth, the writer would have inner satisfaction if the writing is published or considered beneficial for others, besides gaining honorarium (appreciation). Sixth, the writer would gain popularity if the writing is read by many people. It would raise inner satisfaction because of others' appreciation.

However, based on the preliminary observation, it was found that students of STKIP Suar Bangli had problem in producing a writing. It was proven by the fact that there were only 5 proposal of Students' Creativity Program (PKM) produced by the students in 2018, in which the target was 20 proposal. It is unfortunate, because the students had a great opportunity to develop themselves through this program. They could conduct research, public service, open business, and so on.

Some previous researches about students' obstacles in writing or commonly in mastering English have been conducted by some researchers. One of them is Hermayawati (2010). This study revealed that English students faced some problems in mastering because of some factors such as (1) feeling forced to study; (2) less comprehending basic concept/intake; (3) less support from the surrounding; (4) forgetfulness factor; (5) having less opportunity to practice English. Wigati (2014) also conducted study about difficulty in mastering English in which she found that respondents in basic level had difficulty in mastering vocabularies and operating English Grammar. In upper-intermediate respondents, they faced another problem such as difficult in arranging new unclear paragraph, complex sentences, and still making grammatical error.

Furthermore, finding about students' obstacles in mastering English effectively has been delivered by (Megawati, 2016). She found that the students had various difficulty in mastering English. It was caused by various level of English mastery. These difficulties can be seen from English skills or in general. In class with various language competency, the difficulties were varied as well. The research subjects showed difficulty in mastering English based on the skill from the most difficult skill to the easiest as the order of Speaking, Listening, Reading, and Writing. The factor of difficulty in mastering English was highly depended on the level of students' English mastery. For more active students, the most difficult skill was writing but for passive students, speaking was the most difficult skill. Video recording showed that both active and passive students could finish the final test well in term of their confidence and grammar. However, passive students were less confident and could not describe fluently.

Specifically, for English Education Department-STKIP Suar Bangli students, writing is one of important skills that should be mastered. Every semester, students have writing courses. However, there are still many students have problems in writing. Many reasons arouse such 
as difficult in finding ideas, afraid of making grammatical errors, writing is not important, and so on. Therefore, it is essential to find out the main problem of students in writing so there will be an effective way to solve this problem. To find out the main problem of students in writing as well as finding out the students' perception about writing the writer conducted a research entitled 'Perception and Obstacles of College Students in Writing'. Therefore, the research problems of this study can be formulated as follows: 1) What are the perceptions of English Education Department-STKIP Suar Bangli students about writing? and 2) What are the obstacles of English Education Department-STKIP Suar Bangli students in writing?

Sugihartono, et.al (2007:8) stated that perception is an ability of brain to interpret stimuli or process to interpret stimuli which comes into human senses. Human perception has different perspective in sensing. The perception will affect human action in real life. Walgito (2004:70) previously stated that perception is a process of organizing, interpreting the accepted stimuli by organism or individual to be meaningful, and it is an integrated activity in an individual. Response as the consequence of perception can be taken by an individual in many forms. So, any stimulus can be differently interpreted and responded by different individual. Suharman (2005:23) also stated that perception is a process of interpreting information gained by human senses system. There are three aspect of perception which can be considered relevant with human cognition, namely sense recording, pattern recognition, and attention. From these, description it can be summarized that perception is a process initiated from observation so there will be response from individual who aware his/her surrounding through his/her senses.

The obstacles here mean anything that can make the students could not achieve their optimum learning development. According to Mulyono (1999:9) student with learning obstacle will achieve lower than their potency. Burton (1952) in Makmun (2003:307), said that a student is suspected having learning obstacle if he/she shows certain failure in achieving learning goals. Meanwhile, Ahmadi and Supriyono (1991:88) identified learning obstacle as a learning process which is obstructed by some obstacles in achieveing learning goals.

\section{RESEARCH METHOD}

This is a descriptive qualitative research. According to Nazir (2003:4) descriptive method is a research method in studying a status of human group, an object, a set of condition, a system of thought, or an event class at the present time. Sugiyono (2009:21) proposed descriptive method is used to describe or analyze a research finding but it is not used to draw broad conclusion. Further, Hidayat (2010) defined descriptive research as a research method used to find extensive knowledge upon research object in a period of time. According to Punaji (2010), descriptive research 
is a research aimed to explain or describe certain event, circumstance, object in form of human, or anything related to explainable variables by using words or numbers.

Sugiyono (2009) explained that qualitative research method or commonly referred as naturalistic research method is a research method used to study natural object, in which the researcher is the main instrument, while data collection technique is done by interview, inductive data analysis, and the qualitative research finding focuses on meaning rather than generalization. Moleong (2008) stated that qualitative method is a procedure in research which produces descriptive data of which in form of written or spoken words from the observed people. This approach is more directed to the background and method holistically. Qualitative research is a research which uses natural background and interprets phenomena that occur and are carried out by existing methods (interview, observation, and document utilization). Afifuddin and Saebeni (2009:73) argue that qualitative research is a study that produces findings which cannot be reached by using statistical procedure or other quantitative ways. Qualitative research is expected to produce a deep series of utterance, writing, observable behavior from an individual, group, people. Qualitative research aims at gaining common comprehension upon social facts from participant perspective. This comprehension is not previously determined, yet it is gained after doing analysis upon the social facts of which the research focus, and further there is a conclusion in form of common comprehension about these facts.

Based on previous description, it can be concluded that qualitative descriptive research is a research which produces descriptive data in which the researcher is the main instrument, and the variables can be explained both by numbers or words, and the conclusion cannot be used for general conclusion. The purpose of this research is to provide systematic, factual and accurate picture about certain facts. In this present study, these facts are about perception and obstacle of English Education Department-STKIP Suar Bangli students in writing. The research design can be seen in the following chart 01:

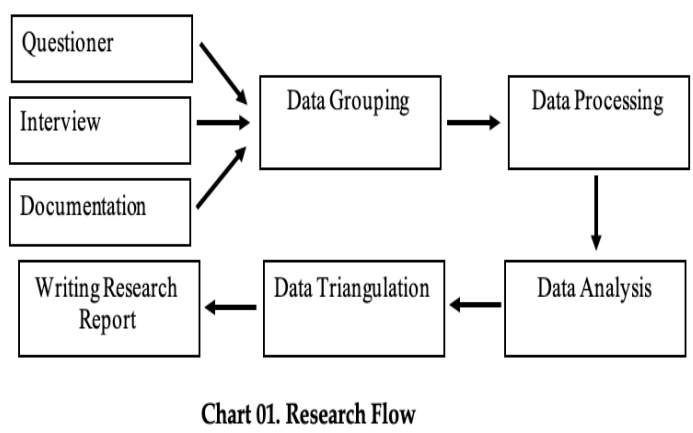

Based on the research design, some instruments were used as follows:

a) Questioner. Questioner was presented in from of questions through Google Drive. All students of English Education Department were asked to answer the questionnaire.

b) Interview. Interview was done to get more detail information about the data that were gained 
from questionnaire. This interview was not conducted to all students. The interview was done to some students who were randomly selected. Besides that, the choosing was done based on the specialty of the given answer and it is considered beneficial and interesting to be elaborated more.

c) Documentation.

Documentation

means collecting all documents that related to the research. There are four kinds of documents as follows:

a) Legal document; documents or files issued by legal institution such as rapport, final semester score, and historical archive.

b) Unofficial document; documents gained from unofficial institution but contain important information related to an event.

c) Primary document; documents taken from legal source or person who becomes informant of the research. This document has originality value and more valid that other documents.

d) Secondary document; documents taken from legal source, other person or any media such as newspaper, research report, paper, and other publications. This document does not have validity and originality value more than primary document.

Miles and Huberman in Sugiyono (2009) described that data analysis in qualitative research is conducted in the process of data collection, after collecting data and after collecting data in a certain period of time. In order to collect good data, so the researcher in analyzing data should follow some steps. The data analysis steps of this research can be sen in the following chart 02 :

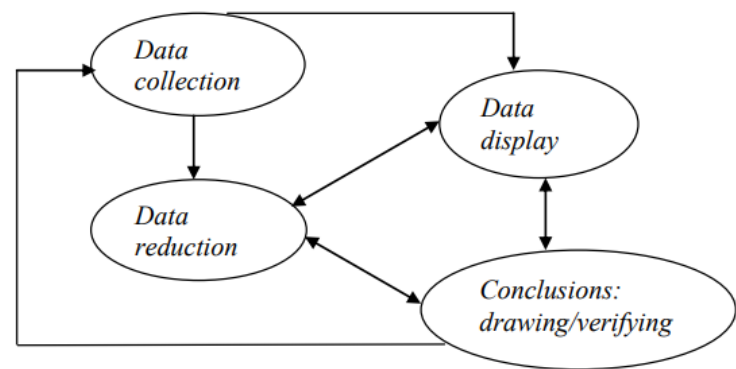

Chart 02. Steps of Data Analysis According to Miles and Huberman (in Sugiyono, 2009)

Based on the above chart 02 , the steps of data analysis can be described as follows:

1) Data Collection is the step to collect data. In this research, there were 3 (three) instrument used namely questionnaire, interview and documentation.

2) Data Reduction is the step to choose, centralize, concern, simplify, abstract, and 
transform the data taken from the field so the result provided clearer information the questionnaire, interview and documentation.

3) Data Display is an arranged group of information so there is possibility to draw a conclusion and take an action. In qualitative research, data display is done in form of short description, chart, table, graph, pictogram, and so on. Through data display, the data is organized so it is easier to understand.

4) Conclusion Drawing or Verification is a step when the researcher draws conclusion based on the data processed through data reduction and data display. This is a temporary conclusion and will change if there is no supporting evidence found in the following data collection. However, if the conclusion is supported by valid and consistent evidences when the researcher back to the field so the conclusion is considered credible.

Data triangulation was also conducted in this research. The triangulation was in form of data collection method. The method of data collection was done through questionnaire, interview and documentation.

\section{FINDING AND DISCUSSION Students' Perception}

Based on the data analysis, it was found that the students thought speaking was the most important skill that should be mastered as a college student. The data showed that $43,48 \%$ of the respondents thought speaking was the most important skill. Writing was considered the second most important skill with $39.13 \%$ responses of the students. Listening and reading came respectively with $13.04 \%$ and $4.35 \%$. The detail picture can be seen in the following graph 01.

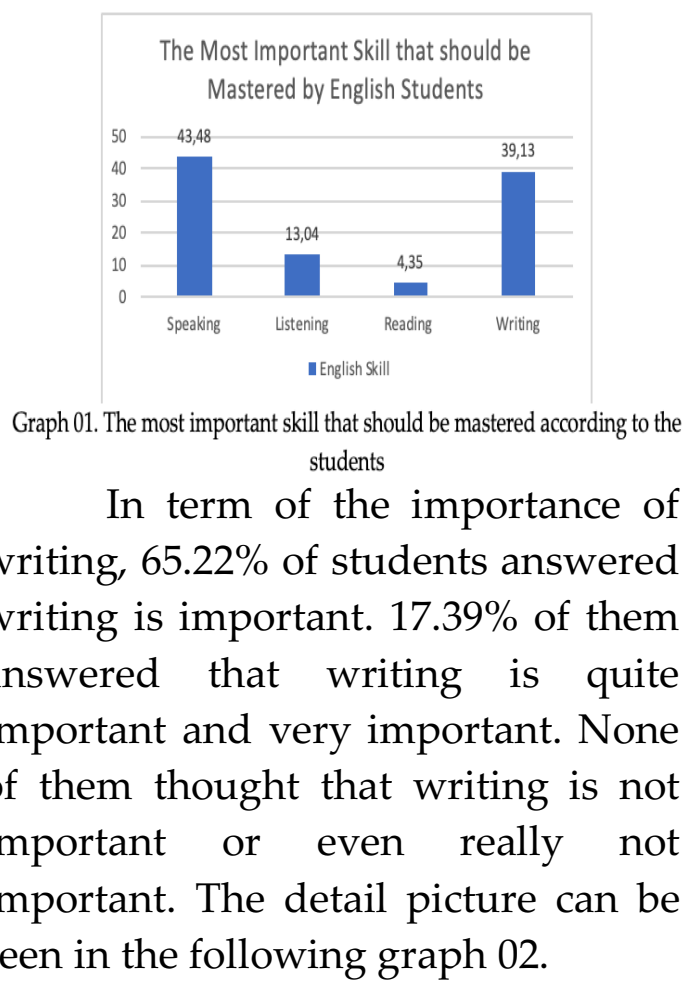
writing, $65.22 \%$ of students answered writing is important. $17.39 \%$ of them answered that writing is quite important and very important. None of them thought that writing is not important or even really not important. The detail picture can be seen in the following graph 02 . 


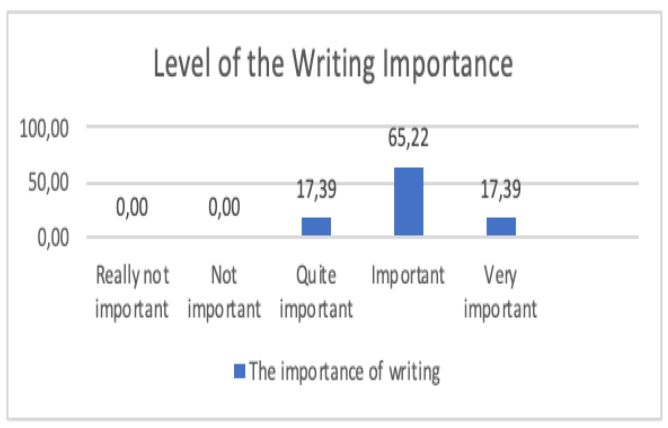

Graph 02. Students' perspective of the importance of writing

When the students were asked what is the importance of writing for themselves, various answers occurred. Those answers can be summarized as follows 1) through writing, they could express their ideas, inspiration, creativity, and feeling, as well as making a reference; 2) developing inspiration; 3) enhancing vocabulary; 4) telling story; 5) being English expertise; 6) improving memory capability; 7) measuring writing skill; 8) doing hobby; and 9) producing a work that can be beneficial for others.

In term of process of writing, the students have their own ideas. Ideally, they thought that writing should be: 1) initiated with idea and inspiration; 2) done by drafting, writing and revising processes; 3) initiated in peaceful condition or in a good mood; and 4) there should be material from writing example.

The students also had their own opinion about how writing skill should be taught in college. Some of their ideas can be formulated as follows: 1) it should be taught based on the process (drafting, writing and revising); 2) should write creative writing based on students' interest; 3 ) direct writing and more practices; 4 ) short explanation about how to write properly; 5) should be in relax and fun situation; 6) should be taught step by step and integrated with three other skills; and 7) should be guided along the process and motivated to write.

In term of writing evaluation, the students answered variously. The answers can be formulated as follows: 1) giving writing assignment but should be provided with feedbacks (comments, re-explanation); 2) giving writing practices; 3 ) rewriting activity; 4) checking writing by experts; 5) multiple editing.

\section{Students' Obstacles}

From the frequency of writing, most of the students did not write frequently. $52.17 \%$ of the students only write when there was an assignment for them. $8.70 \%$ students write every day. $26.09 \%$ of them write once in a week and $13.04 \%$ students write once in a month. The detail picture can be seen in the following graph 03.

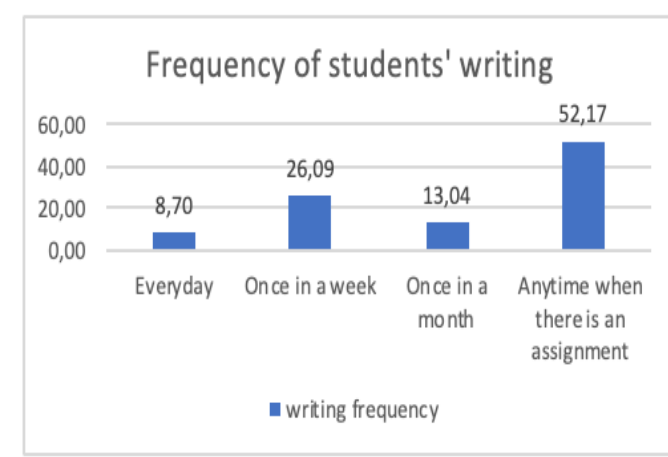

Graph 03. Frequency of students' writing

From the data analysis, it was found that the students had many obstacles in writing. Those obstacles were 1) difficult in finding inspiration and idea; 2) technical aspect of writing (tenses, grammar, diction, 
vocabulary, coherence, cohesion); 3) difficult to start writing; 4) have no time; 5) laziness; and 6) determining flow of writing. From these obstacles, the most challenging obstacle was finding idea with $30.43 \%$. Then, the most challenging obstacle that should be solved was technical writing problem, time of writing, laziness and determining flow of writing with percentage of $26.09 \%, 21.74 \%, 17.39 \%$, and $4.35 \%$ respectively. The clear picture can be seen in the following graph 04.

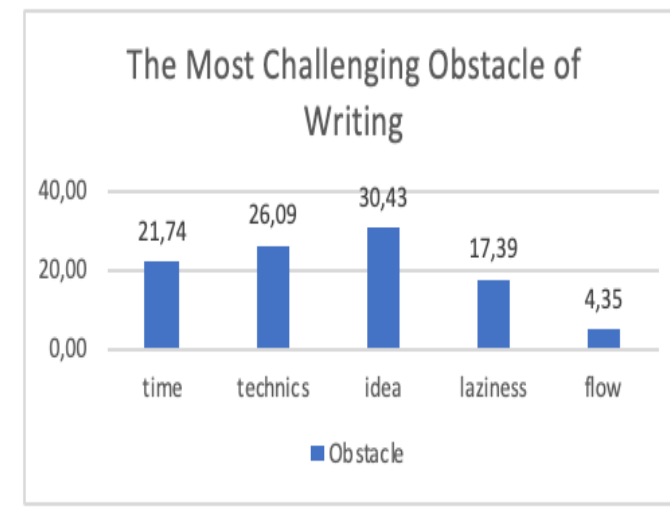

Graph 04. The Most Challenging Obstacle of Writing

The data analysis also discovered the reason that can make the students want to write. The reasons can be formulated as follows: 1) having an inspiration/idea; 2) having an assignment; 3) being in a good mood; 4) there is time allocation for writing; 5) having motivation; and 6) being in supportive situation and condition.

Based on the data analysis, we found that writing was considered as the second most important skill that should be mastered (39.13\%) after speaking. It means that the students were aware that they should master writing skill for the sake of their study. However, it does not mean that they ignore the other skills besides writing. From the interview, all of the students aware that they could not master only one skill. All of the skills should be mastered in order to master English comprehensively. Specifically, all of the students considered writing is important for their study. It can be seen from the data showing none of the students answered writing as not important. It means that the students aware as an English student they should be able to write properly.

Writing was considered important for many reasons. The most expressed reason was because writing could be a medium to express ideas, inspiration, creativity, and feeling, as well as making a reference. It is important since they should write almost all the time in following their study at campus. This perspective is in line with Vicki and Monette (2005:3) who stated that writing is an explorative procs which provides benefit for both teacher and students at the same content. It is one of language skills that should be taught because it has an important role in social life to express ideas, feeling and opinion in order to interact with others. I other hand, few of the students considered writing as a hobby in which they could produce beneficial literal works for others as readers. Actually, consider writing as a hobby is the best way to improve their skill because they will always practice their writing skill all the time without waiting for assignment to write. It is also one of the benefits that 
can be gained from writing as mentioned by Komaidi (2008). He mentioned that there are six benefits of writing in which one of them is selfsatisfaction after the writing is published.

The students told that the writing should be done ideally in supporting condition. It means that they would be able to write if they are in relax and fun condition. The situation did not stress them to write. They thought that process of writing should be done with drafting, writing and editing. These three steps are in line with Vicki and Monette (2005:11) who stated that there are four steps of writing namely, (1) pre-writing, (2) drafting, (3) revision, and (4) editing. It means that the students had sufficient information about how the process should be done. Therefore, the thought the process of teaching writing skill should fulfill these writing process. Besides that, creating supportive condition to write is also important to raise their willingness or mood to write. Moreover, some explanation should be delivered by the lecturer before giving them series of writing practices. It is intended to give the students clear information about how to write properly.

In line with students' perceptive on how the process of teaching writing, evaluation on writing should be designed based on the demand of writing improvement. They though that evaluation of writing should be done simultaneously. Evaluating writing should be accompanied with some improvements along the process of writing. They need more feedbacks on their writing in order to know their weaknesses. So, evaluation of the writing should not be done at once in the end of writing. Some activities were proposed as the evaluation of writing such as rewriting activity, multiple editing, and expert checking. Considering the data of students' perspective, it can be concluded that the students aware of the importance of writing for their study. They also aware of how the writing process ideally which minimum comprises of drafting, writing and editing. Moreover, evaluation of writing should be done based on the process of writing simultaneously. However, the students did not write frequently. Most of the students (52.17\%) only write when they got assignment from the lecturer. It means that the willingness of writing was still low. They need to be forced to write. This condition was caused by some obstacles which can be summarized into no time of writing, writing technique, finding idea, laziness and flow of writing. The most challenging obstacle was finding the idea of writing. Most of the students were stuck when starting to write if they had no idea to write. These obstacles were in line with the reasons that can make them to write such as getting 1) having an inspiration/idea; 2) having an assignment; 3) being in a good mood; 4) there is time allocation for writing; 5) having motivation; and 6) being in supportive situation and condition. These obstacles potentially affected students' writing score. There 
is possibility that the student will get low score of writing skill if these obstacles are not solved.

Actually, the problem of finding idea can be solved by using project-based learning model. It has been proven by Wahyuni and Lestari (2017) who revealed that students writing score in paragraph writing was improved by the implementation of Project Based learning material. It helped the students to find idea in pre-writing step.

\section{CONCLUSION}

From the data analysis and discussion of this research, it can be concluded that the students of English Education Department aware of the importance of writing in their life in which none of them answered writing as not important. They also considered writing as the second most important skill that should be mastered after speaking. In term of teaching writing skill, they thought it should be taught through the process of writing (drafting, writing and revising) in relax and fun situation with many practices. The evaluation of writing should also provide feedbacks for their writing improvement. Considering the obstacles faced by the students in writing, finding idea was the most challenging obstacle that should be solved by the students besides having no time to write, technical writing problem, laziness and determining flow of writing. However, they also proposed some reasons that may trigger them to write such as having idea/inspiration, having assignment, being in a good mood, there is time allocation for writing, having motivation, and being in supportive situation and condition.

Based the conclusion, it is suggested to lecturers of English Education Department of STKIP Suar Bangli who teach writing skill to consider the obstacles faced by the students. It is suggested to teach by using project-based learning in writing skill based on the result $f$ research conducted by Wahyuni and Lestari (2017). They must make sure the students will go through proper process of writing starting from prewriting, drafting, writing, revision and editing. This process will make the students improve their writing quality. Besides that, the evaluation should be in form of performance assessment which one of the suggested is that portfolio assessment. By using this assessment, the students will record their weakness and improvement starting from prewriting. Above all, the lecturers have to create relax and fun atmosphere as well as motivating the students to write. 


\section{REFERENCES}

Afifuddin, dan Saebani, Beni Ahmad. 2009. Metodologi Penelitian Kualitatif. Bandung: Pustaka Setia.

Ahmadi, A. \& Supriyono, W. 1991. Psikologi Belajar. Jakarta: Rineka Cipta.

Hermayawati. 2010. Analisis Kesulitan Belajar Bahasa Inggris Mahasiswa. Jurnal Sosio-Humaniora Vol.1 No. 1 September 2010 ISSN: 20871899.

Hidayat, A.A. Alimul. 2010. Metode Penelitian Kesehatan Paradigma Kuantitatif. Jakarta: Health Books.

Komaidi, Didik. 2007. Aku Bisa Menulis. Panduan Praktis Menulis Kreatif Lengkap. Yogyakarta: Sabda Media.

Makmun, Abin Syamsudin. 2003. Metode Belajar dan Kesulitankesulitan Belajar. Bandung: Tarsito.

Megawati, Fika. 2016. Kesulitan Mahasiswa dalam Mencapai Pembelajaran Bahasa Inggris secara Efektif. Jurnal Pedagogia ISSN 2089-3833 Volume. 5, No. 2, Agustus 2016.

Moleong, Lexy J. 2008. Metodologi Penelitian Kualitatif. Bandung: PT Remaja Rosdakarya.

Mulyono, A. 1999. Pendidikan Bagi Anak Berkesulitan Belajar. Jakarta: Rineka Cipta.

Nazir, Moch. 2003. Metode Penelitian. Jakarta: Salemba Barat.
Punaji, Setyosari. 2010. Metode Penelitain dan Pengembangan. Jakarta: Kencana.

Suharman. 2005. Psikologi Kognitif. Surabaya: Srikandi.

Sugihartono, dkk. 2007. Psikologi Pendidikan. Yogyakarta: UNY Press.

Sugiyono. 2009. Metode Penelitian Kuantitatif, Kualitatif dan RED. Bandung: Alfabeta.

Vicki, Urquhart, and Monette, Mclver. 2005. Teaching Writing in the Content Areas. United States of America: ASCD.

Wahyuni, Tri dan Lestari, Sri. 2017.

Persepsi Mahasiswa terhadap Pembelajaran Paragraph Writing pada Penggunaan Bahan Ajar Berbasis Project Based Learning dengan Konsep Graphic Organizer. Prosiding Seminar Hasil Penelitian dan Pengabdian kepada Masyarakat UNIPMA 2017. Walgito, B. 2004. Pengantar Psikologi Umum. Jakarta: Andi Jakarta. 